\title{
Costs and externalities of road transport in Portugal
}

\author{
M. Lopes ${ }^{1}$, P. Gomes ${ }^{2}$, H. Martins ${ }^{1} \&$ C. Borrego ${ }^{1}$ \\ ${ }^{1}$ CESAM, Department of Environment and Planning, \\ University of Aveiro, Portugal \\ ${ }^{2}$ GOVCOPP, Unit of Social, Legal and Political Sciences, \\ University of Aveiro, Portugal
}

\begin{abstract}
Urban dispersion (sprawl) is a reality, however unplanned it may be. Its supporters advocate contact with nature, space and intimacy, however disadvantages include land consumption, public infrastructure and mobility costs and housing prices. The Research Project "Costs and Benefits of Urban Dispersion on a local scale" seeks to contribute to the debate with an objective approach based on the quantification of costs, externalities and benefits of different urban settlement patterns. This paper presents one of the Project's tasks, the one concerning mobility costs, including externalities. Quantified costs include investment, inspection, insurance, energy and maintenance, as well as external social and environmental costs for road transport, the most significant transport mode operating on a local scale. Different methods are combined depending on available data sources in order to achieve figures for each of the cost components per vehicle- $\mathrm{km}$, ton-km and passenger-km at prices of 2005. Preliminary results for direct costs suggest that in light vehicles investment costs are responsible for the largest share of the totals, while energy costs are the most relevant cost component in heavy vehicles. Heavy duty passenger transport is significantly more expensive than their counterparts. Externalities may mount up to around half of the total costs for some road vehicles. Keywords: urban dispersion; road transport; internal costs; externalities.
\end{abstract}

\section{Introduction}

The urban future of Europe is today a matter of great concern, since approximately $75 \%$ of the European population lives in urban areas, a number 
predicted to rise to $80 \%$ by 2020 [1]. More than a quarter of the European territory is now directly affected by urban land use; between 1990 and 2000, urban areas have expanded $5.5 \%$ in average, with rates varying regionally from $0.7 \%$ to $40 \%$ [1].

Historically, in comparison with North-American cities, European cities have traditionally been much more compact, with a dense historical core shaped before the emergence of modern transport systems; however, urban sprawl is now a common phenomenon throughout Europe [1], even in Mediterranean urban areas, which are now experiencing a change towards more dispersed and horizontal growth at the expense of agricultural, forested and natural environments [2]. This is raising concerns about the potential negative impact on urban sustainability [1-3].

Dispersion has not had many proponents amongst great city thinkers. The exception may have been F. L. Wright whom conceived his ideal city Broadacre - as an urban-rural hybrid in which all construction would spread out over the landscape and where "the city would be the nation" [4]. The two dominant motives in favour of urban compaction are the reduction of pollution, and the reduction of the loss of open countryside to urban uses. The reason behind the first motive is that urban containment will reduce the need for travel which is the fastest growing and least controlled contributor to atmospheric emissions, and hence global warming - by facilitating shorter journeys and inducing greater supply and use of public transport.

However, dispersion today is a reality. It has been happening in a nonplanned way but one which is practised and accepted, and has become the natural subject of numerous scientific research publications and studies [5].

It has been demonstrated that sprawl elevates the cost of urban services by increasing the distance between new development and the established infrastructure of roads, sewer lines, and transit systems [5]. Other authors have associated sprawling urban development patterns with increased vehicle travel and congestion [6], loss of prime agricultural lands [7], and, even, increased rates of obesity in children and adult populations [8].

Other authors [9], however, claim that the environmental benefits resulting from urban compaction are doubtful and that higher urban densities are unlikely to bring about the high quality of life that centrists promise. Although some reduction in energy consumption might be expected from compaction, they argue that a large centralised city can often result in greater traffic congestion, and fuel efficiency is greatly reduced through increasing travel times and slower traffic speeds; congestion and dangerous traffic leads to a worse pedestrian environment, public transport is often caught up in congested streets, and parking is a serious problem, affecting the character and function of city streets.

As far as mobility is concerned the transport sector is one of the human activities with the largest environmental impact, with effects on human health, ecosystems and heritage. Transport is an important source of greenhouse gases (GHG), contributing also to atmospheric pollution problems, such as acidification, eutrophication and tropospheric ozone. Several methodologies [10, 11] have been developed in order to estimate energy use externalities and costs, 
particularly in the transport sector. In terms of costs evaluation there are few European ; more quantitative research is to be found in the USA, such as the research studies coordinated by Robert Burchell [5].

\section{2 "Costs and benefits of urban dispersion on a local scale": project overview}

The Project "Costs and Benefits of Urban Dispersion on a local scale" is a 3yearlong multidisciplinary research project funded by the Portuguese Foundation for Science and Technology. Its main objective is to evaluate, as precisely as possible, the costs and benefits of an urban fragmented and dispersed structure. Thus, in the end, this Project should achieve conclusions and recommendations on how to deal with the growth of dispersion and on desirable planning scenarios of existing dispersed areas in terms of infrastructure, mobility and/or construction load.

To do so, and following its methodology, the Project further encompasses the following tasks [12]:

- Characterization of urban dispersion on a local scale;

- Identification of the whole range of costs to consider in comparing different urban forms;

- Comparative evaluation of infrastructure and mobility costs;

- To formulate a concept of quality of life, to be translated in an algorithm which encompasses different opinion groups;

- Confrontation of costs and quality of life (QoL) in an array of scenarios;

- Characterization of the real estate market in the process of urban dispersion.

Costs will cover public infrastructure costs (including networks, all public space and public equipments) and mobility costs and externalities per transport mode. These costs should be put side by side with benefits inevitably associated with the QoL this type of urbanization is expected to offer to the citizens.

QoL is a subjective concept that changes individually and within different stakeholders. This research intends to transform this concept into an algorithm integrating this variability, based on current literature, similar previous studies and on the answers to a questionnaire applied to the inhabitants of two case studies: the Aveiro-Ílhavo urban area (population of 100,000 inhabitants), located at the Portuguese central coastline, and Évora, a smaller city located inland (population of 48,000 inhabitants).

This evaluation will be expressed quantitatively through the development of a utility function that represents opinions on QoL, an integrated cost for local infrastructure and mobility and a methodology to relate the two functions for a variety of scenarios.

The project outcome will be the formulation of a comparative opinion, expressed in cost-benefit terms, between the various typologies of dispersed occupation and, also, between these and those of continuous occupation. 
This paper will focus on the task related with mobility costs and externalities, and intends to present the methodology applied and the results obtained for road transport, the most significant transport mode in urban sprawl areas.

\section{Costs and externalities of road transport in Portugal}

\subsection{Definitions and scope}

Definitions of internal and external costs are consensual: internal costs are those directly borne by transport users, while external ones are those borne by others than the transport user causing them. Despite this clear-cut definition, classification of certain cost components, such as accident and congestion costs, as internal or external is controversial, mostly due to differing interpretations on the extent of cost internalization mechanisms' coverage of externalities [13].

Internal costs may be divided into investment and operation costs. Investment costs are those related to vehicle purchase, including its price, taxes interest. Operation costs, in their turn, refer to vehicle operation and may be divided into fixed and variable ones. Fixed costs are independent of intensity of use, such as legally imposed (in Portugal) circulation taxes and vehicle inspections; variable ones depend on the intensity of vehicle usage, including maintenance, tolls, parking and energy consumption, among others. There are other direct costs of road transport, such as those incurring from infrastructure development and maintenance, freight handling, labour, organization [14].

Among external costs, the most relevant ones are environmental (pollution, noise, climate change, nature and landscape depredation, and other impacts upand downstream of the transport system), additional costs in urban areas (such as barrier effects and space shortage), accidents (medical care, production loss, pain and sorrow) and congestion (time wastes and increasing operation costs) [15].

In this Project, however, costs are not assessed from the users' standpoint (market prices paid), but from a systemic/societal one, which implies calculating integrated costs (both internal and external). Thus, mechanisms of internalizing external costs and financing the system's operation, such as capital costs, taxes and tariffs, are discarded from said market prices. Costs relating to handling and labour are not included, as the purpose is to restrict cost identification to those components associated with the act of displacement. Moreover, infrastructure costs are not accounted for either since they are object of a specific Project task.

Consequently, this paper will assess the following direct cost components: investment, inspection, insurance, energy/fuel and maintenance. External costs account both social and environmental costs. The study will focus on road transport, as it is the most relevant transport mode in the two case-studies, which have no metro or tram lines. Suburban rail transport as well as cycling and walking will be integrated in a subsequent phase of the Project.

\subsection{Methodology}

The purpose of this assessment is to provide multipliers which together with data inputs on mobility patterns from the survey undertaken in the case studies, will 
allow the estimation of mobility costs according to the type of urban settlements. Thus, average, not marginal, costs are sought, as the objective is to quantify costs of particular displacement patterns and not to identify the impact of additional users on the system (marginal), usually employed when devising internalization mechanisms.

The transport modes considered are: cars, motorcycles, buses and coaches, and light (LDV) and heavy duty vehicles (HDV).

For each transport mode, costs per vehicle-km and user-km (passenger or ton) were calculated in function of average vehicle lifetimes, mileages and average occupancy rates or loads. The data reference year was 2005, the most recent complete statistical datasets, even though some data refers to other years. However, monetary values were inflated to 2008 prices via Eurostat's Consumer Price Index, in order to ensure comparability with the benefits' vector, whose data also derives from the aforementioned survey. Whenever available, data was gathered from secondary sources; otherwise data was collected directly from the companies. Depending on available sources, approaches for cost calculation were either top-down (departing from aggregate values for the whole of the vehicle fleet) or bottom-up (identifying costs for one single average vehicle). Table 1 summarizes data sources and methods used for establishing internal costs.

Table 1: $\quad$ Data sources and methods for internal costs.

\begin{tabular}{|c|c|c|c|c|c|}
\hline & \multicolumn{5}{|c|}{ Transport Mode } \\
\hline Variable & Passenger Cars & $\begin{array}{l}\text { Light Duty } \\
\text { Vehicles }\end{array}$ & Buses/Coaches & $\begin{array}{l}\text { Heavy Duty } \\
\text { Vehicles }\end{array}$ & Motorcycles \\
\hline $\begin{array}{l}\text { Number of } \\
\text { vehicles }\end{array}$ & [16] & {$[16]$} & {$[16]$} & {$[16]$} & [16] \\
\hline $\begin{array}{l}\text { Vehicle } \\
\text { fleet: age } \\
\text { structure }\end{array}$ & {$[17]$} & {$[17]$} & [17] & {$[17]$} & {$[17]$} \\
\hline $\begin{array}{l}\text { Average } \\
\text { lifetime }\end{array}$ & $\begin{array}{l}\text { Enquiry to the } \\
\text { official vehicle } \\
\text { recycling } \\
\text { network } \\
\text { (VALORCAR) }\end{array}$ & $\begin{array}{l}\text { Own reasoning: } \\
\text { analogy w/ } \\
\text { passenger cars }\end{array}$ & $\begin{array}{l}\text { Enquiry to } 6 \text { public } \\
\text { transport operators }\end{array}$ & $\begin{array}{l}\text { Own reasoning: } \\
\text { analogy w/ } \\
\text { bus/coach. }\end{array}$ & $\begin{array}{l}\text { Own reasoning: } \\
\text { analogy w/ } \\
\text { passenger cars. }\end{array}$ \\
\hline Mileage & [18] & [18] & $\begin{array}{l}\text { Enquiry to } 6 \text { public } \\
\text { transport operators }\end{array}$ & $\begin{array}{l}\text { Own reasoning: } \\
\text { analogy w/ } \\
\text { bus/coach }\end{array}$ & [18] \\
\hline $\begin{array}{l}\text { Load factor / } \\
\text { Occupancy } \\
\text { Rates }\end{array}$ & [19] & [19] & [19] & [19] & [19] \\
\hline $\begin{array}{l}\text { Investment } \\
\text { costs }\end{array}$ & $\begin{array}{l}\text { Own reasoning } \\
\text { using data from a } \\
\text { specialty } \\
\text { magazine }\end{array}$ & $\begin{array}{c}\text { Own reasoning } \\
\text { using data from a } \\
\text { specialty } \\
\text { magazine }\end{array}$ & $\begin{array}{l}\text { Enquiry to } 8 \text { public } \\
\text { transport operators } \\
\text { and constructors }\end{array}$ & $\begin{array}{l}\text { Enquiry to } 7 \text { freight } \\
\text { transport operators } \\
\text { and constructors }\end{array}$ & $\begin{array}{c}\text { Own reasoning } \\
\text { using data from a } \\
\text { specialty } \\
\text { magazine }\end{array}$ \\
\hline $\begin{array}{l}\text { Inspection } \\
\text { Costs }\end{array}$ & $\begin{array}{l}\text { Own reasoning, } \\
\text { based on vehicle } \\
\text { lifetime and } \\
\text { applicable } \\
\text { legislation }\end{array}$ & $\begin{array}{l}\text { Own reasoning, } \\
\text { based on vehicle } \\
\text { lifetime and } \\
\text { applicable } \\
\text { legislation }\end{array}$ & $\begin{array}{c}\text { Own reasoning, } \\
\text { based on vehicle } \\
\text { lifetime and } \\
\text { applicable legislation }\end{array}$ & $\begin{array}{c}\text { Own reasoning, } \\
\text { based on vehicle } \\
\text { lifetime and } \\
\text { applicable legislation }\end{array}$ & N/A \\
\hline $\begin{array}{l}\text { Insurance } \\
\text { Costs }\end{array}$ & $\begin{array}{l}\text { Enquiry to } 2 \\
\text { insurance } \\
\text { companies }\end{array}$ & $\begin{array}{l}\text { Enquiry to } 2 \\
\text { insurance } \\
\text { companies }\end{array}$ & $\begin{array}{c}\text { Enquiry to } 1 \\
\text { insurance company }\end{array}$ & $\begin{array}{l}\text { Enquiry to } 2 \\
\text { insurance companies }\end{array}$ & $\begin{array}{l}\text { Enquiry to } 2 \\
\text { insurance } \\
\text { companies }\end{array}$ \\
\hline $\begin{array}{l}\text { Energy } \\
\text { Costs }\end{array}$ & $\begin{array}{l}\text { Own reasoning, } \\
\text { combining } \\
\text { several sources }\end{array}$ & $\begin{array}{l}\text { Own reasoning, } \\
\text { combining } \\
\text { several sources }\end{array}$ & $\begin{array}{l}\text { Own reasoning, } \\
\text { combining several } \\
\text { sources }\end{array}$ & $\begin{array}{l}\text { Own reasoning, } \\
\text { combining several } \\
\text { sources }\end{array}$ & $\begin{array}{l}\text { Own reasoning, } \\
\text { combining } \\
\text { several sources }\end{array}$ \\
\hline $\begin{array}{l}\text { Maintenance } \\
\text { Costs }\end{array}$ & {$[20]$} & {$[20]$} & $\begin{array}{l}\text { Enquiry to } 6 \text { public } \\
\text { transport operators } \\
\text { and constructors }\end{array}$ & $\begin{array}{l}\text { Enquiry to } 6 \text { freight } \\
\text { transport operators } \\
\text { and constructors }\end{array}$ & $\begin{array}{l}\text { Enquiry to } \\
\text { authorized repair } \\
\text { services for the } 5 \\
\text { most sold brands } \\
\text { in } 2005\end{array}$ \\
\hline
\end{tabular}


Studies on external costs are more abundant, yet results reached are varied, depending both on differing conceptual and methodological factors and on "the specifics of the situations" (countries' distinct settlement patterns and vehicle fleets) [21]. As a consequence, data explicitly concerning the Portuguese situation has been privileged whenever possible.

Moreover, figures also depend on the type of costs under scrutiny: marginal or average [21]. This paper deals with average costs. Only two sources were found to fulfil these prerequisites $[25,26]$.

Table 2 synthesises the most relevant variables of each transport mode's vehicle fleet: number of vehicles, their average lifetime and average mileages, both annual and throughout their life. All cost calculation, namely that following a top-down approach, will refer back to these data.

Table 2: $\quad$ Vehicle fleet characteristics per transport mode in Portugal, 2005.

\begin{tabular}{|c|cccc|}
\hline Transport Mode & $\begin{array}{c}\text { Nb. of } \\
\text { Vehicles }\end{array}$ & $\begin{array}{c}\text { Average } \\
\text { Lifetime } \\
(\text { years })\end{array}$ & $\begin{array}{c}\text { Average mileage } \\
\text { throughout lifetime } \\
(\mathrm{km})\end{array}$ & $\begin{array}{c}\text { Average } \\
\text { annual mileage } \\
(\mathrm{km})\end{array}$ \\
\hline Passenger Cars & 4.795 .147 & 17,9 & 200.000 & 11.187 \\
\hline LDV & 788.018 & 15,1 & 250.000 & 16.544 \\
\hline Buses/Coaches & 12.558 & 16,8 & 1.102 .778 & 65.642 \\
\hline HDV & 157.586 & 16,1 & 1.378 .472 & 85.651 \\
\hline Motorcycles & 487.578 & 12,3 & 53.526 & 4336 \\
\hline
\end{tabular}

\subsection{Results}

\subsubsection{Internal costs}

Table 3 presents results for all of the internal cost components for each transport mode. Figure 1 displays the cost structure per transport mode.

Table 3: Internal costs per transport mode (rows in white refer to $€ /$ vehicle$\mathrm{km}$, light grey ones to $€ /$ passenger-km and those in dark grey to $€ /$ ton-km).

\begin{tabular}{|c|cccccc|}
\hline Transport Mode & $\begin{array}{c}\text { Investment } \\
\text { Costs }\end{array}$ & $\begin{array}{c}\text { Inspection } \\
\text { Costs }\end{array}$ & $\begin{array}{c}\text { Insurance } \\
\text { Costs }\end{array}$ & $\begin{array}{c}\text { Energy } \\
\text { Costs }\end{array}$ & $\begin{array}{c}\text { Maintenance } \\
\text { Costs }\end{array}$ & $\begin{array}{c}\text { Total } \\
\text { (Internal } \\
\text { Costs) }\end{array}$ \\
\hline Passenger Cars & 0,089 & 0,002 & 0,023 & 0,045 & 0,016 & 0,229 \\
& 0,036 & 0,001 & 0,009 & 0,018 & 0,006 & 0,072 \\
\hline $\begin{array}{c}\text { Light Duty } \\
\text { Vehicles }\end{array}$ & 0,061 & 0,002 & 0,016 & 0,039 & 0,016 & 0,142 \\
Buses/Coaches & 0,205 & 0,005 & 0,052 & 0,130 & 0,053 & 0,449 \\
\hline Heavy Duty & 0,165 & 0,001 & 0,018 & 0,227 & 0,144 & 0,643 \\
Vehicles & 0,070 & 0,00004 & 0,001 & 0,008 & 0,005 & 0,020 \\
\hline Motorcycles & 0,018 & 0,001 & 0,009 & 0,197 & 0,050 & 0,329 \\
\hline & 0,065 & - & 0,049 & 0,017 & 0,021 & 0,156 \\
\hline
\end{tabular}



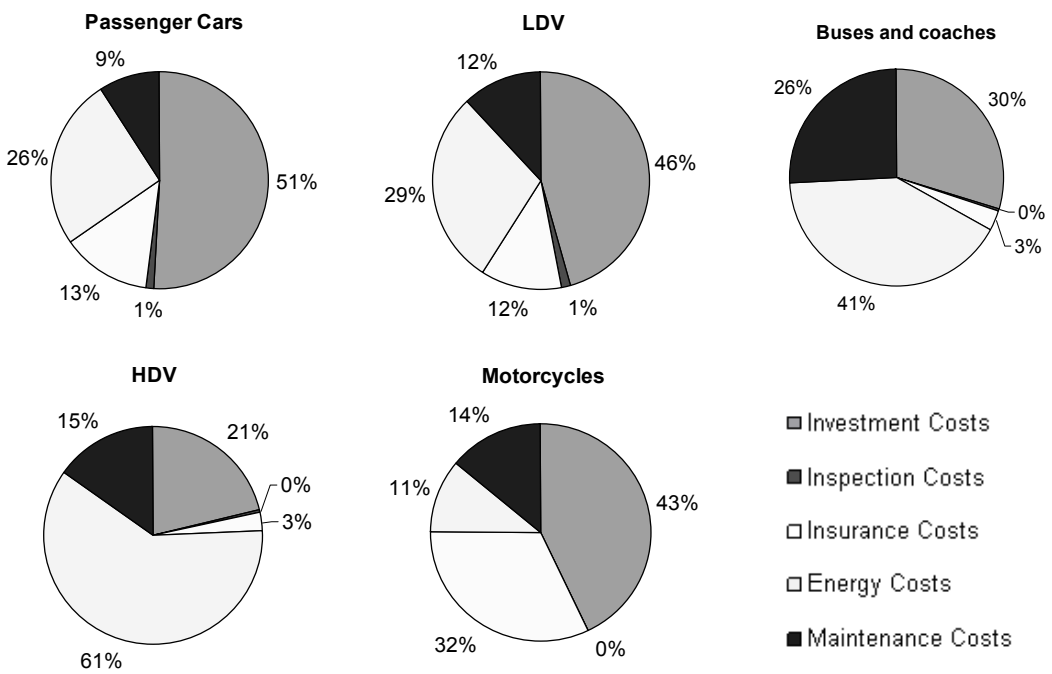

Figure 1: Internal cost (€/vehicle-km) structure for a) passenger cars; b) LDV; c) buses and coaches; d) HDV and e) motorcycles.

Buses and HDV have the highest total costs per $\mathrm{v}-\mathrm{km}$, due to fuel consumption and maintenance. The latter are particularly high for buses, likely reflecting intense use and tighter safety and maintenance requirements due to the type of service provided. Investment costs are the most important component for the remaining modes. While energy is the second most expensive component for light automobiles, in motorcycles it is insurance costs that rank second. Vehicle mileage is important to explain differences in total costs, namely in LDV's good performance, in motorcycles' expensiveness and HDV's better performance comparing to buses. Inspection costs are residual in all modes.

Conversely the costs per passenger-km and per ton- $\mathrm{km}$ are significantly lower for heavy vehicles than for light ones because load factors are higher. LDV present quite high costs per vehicle-km due to quite low load factors.

\subsubsection{External costs}

Macário et al. [22] estimate average external costs of transport for 2005 for environmental (air pollution, global warming and noise), delay due to congestion and accident costs. However, there is no disaggregation per transport mode for many of the cost components, which hampers comparability and the ultimate purpose of this task.

Table 4 presents the results of dividing total costs per transport mode or for the whole of road transport in 2005 from [25] by data from Table 2 (except for delay costs, originally in $€ /$ vehicle-km). No arbitrary attribution of costs was made, that is why for some cost components values are identical for all transport modes. Figure 2 displays the external cost structure per transport mode. 
Table 4: $\quad$ External costs of transport in $€ /$ vehicle-km.

\begin{tabular}{|c|ccccc|}
\hline Input data & Passenger Cars & LDV & Buses/Coaches & HDV & Motorcycles \\
\hline Macário et al. [22] & 0,025 & 0,049 & 0,334 & 0,092 & 0,046 \\
INFRAS/IWW [23] & 0,147 & 0,086 & 0,85 & 0,306 & 0,404 \\
\hline
\end{tabular}
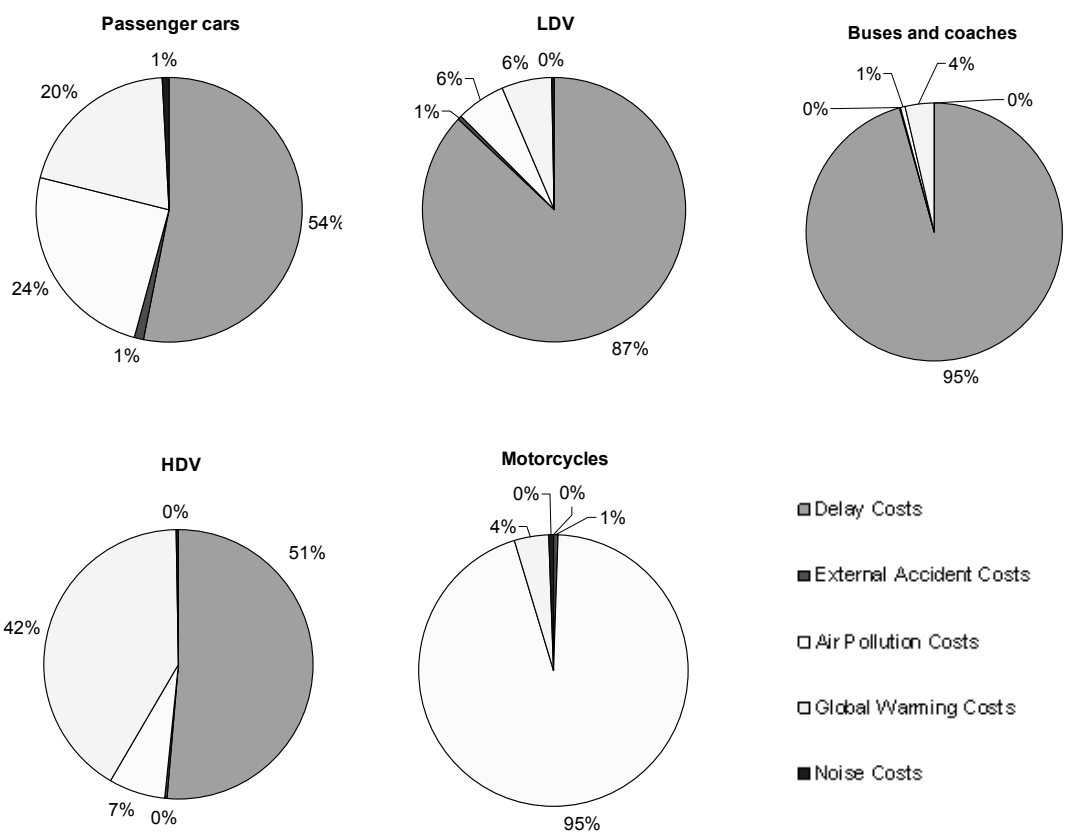

Figure 2: $\quad$ Share of different external costs (€/vehicle-km) for a) passenger cars; b) LDV; c) buses and coaches; d) HDV and e) motorcycles.

INFRAS/IWW's [23] report on external costs in 2000 only presents total average cost estimates in $€ /$ passenger-km and $€ /$ ton-km, but it disaggregates them per transport mode. These total costs include accidents, air pollution, upand downstream processes, climate change, noise, nature and landscape and urban effects, excluding delay costs, the most relevant component in [22]. Such aggregate data per mode still allow the ultimate goal of our research (integrated costs per mode) but it diminishes analytical possibilities. Despite the absence of input data on load factors, costs in $€ /$ vehicle-km were estimated with analogous data from an earlier version of this report [19]. Data based on this source is also shown in Table 4.

Estimates stemming from [23] are quite higher (ca. 2-9 times) than those derived from [22]. However, it is not possible to know whether such discrepancies are only due to it encompassing more cost components or to methodologies adopted since there is no disaggregation per component in [26]. 
Still, both sources suggest that buses create higher external costs per vehicle$\mathrm{km}$. But while calculations deriving from [22] rank HDV second, LDV third, motorcycles fourth and cars in the end, [23] claims that motorcycles cause the second highest external costs, followed by HDV, cars and, finally, LDV. Motorcycles are responsible for the highest external costs in $€ /$ passenger-km and LDV in $€ /$ ton-km. High mileages also make buses cheaper in $€ /$ passenger-km, with lower costs than cars for [23] and almost identical ones for [22].

Observing cost structures per transport mode, delay costs are the most relevant ones for all modes (except motorcycles, for which there is no information) and massively so for LDV and buses. In passenger cars and HDV, delays mount up to half of the external costs; for cars the majority of the remaining costs are shared between air pollution and global warming, whereas for HDV global warming is accountable for more than $40 \%$ of external costs. In motorcycles, where delay costs due to congestion are not contemplated, almost all external costs are due to air pollution.

\subsubsection{Integrated costs}

Given such discrepancies in figures for external costs, there are also differences in the proportion of external costs in integrated costs, depending on the source used. Thus, external costs may range from $10 \%$ to $39 \%$ of integrated costs for passenger cars, between $26 \%$ and $38 \%$ for LDV, 34\% and $57 \%$ for buses and coaches, $22 \%$ and $48 \%$ for HDV and $23 \%$ and $72 \%$ for motorcycles. These results seem to confirm those from Burchell et al. [5] that user costs are higher than external ones (society and government). The only exception could be motorcycles and buses and coaches.

Concerning integrated costs in $€ /$ vehicle-km, both estimates suggest buses and coaches and HDV to be the most expensive and LDV the cheapest transport mode. INFRAS/IWW's [23] appraisal of external costs for motorcycles leads to their integrated costs surpassing cars', while according to Macário et al. [22], cars are more expensive than motorcycles. In $€ /$ passenger-km, both sources suggest motorcycles to be the most expensive, followed by cars and buses. In $€ /$ ton-km, heavy vehicles are cheaper than light ones according to both accounts.

\section{Conclusions}

Results underline the importance of load factors for rational use of transport, namely in offsetting higher costs per vehicle-km for HDV and buses, stressing the need to face one of the most pressing challenges of today's urban planning: how to provide public transport in low density areas characterizing urban dispersion?

Results also confirm energy/fuel as one of the major issues in urban transport: not only do energy costs play a relevant role in direct costs, a tendency that will probably be reinforced with increasing fuel prices, but also external costs deriving from fuel consumption (air pollution and global warming) are quite significant. More energy efficient vehicles and cleaner fuels are two related fields through which this problem should be addressed. 
Congestion, an important issue for the discussion of urban dispersion, is also confirmed as one of the most relevant problems in mobility planning. Delay costs are undoubtedly significant and cause important environmental impacts, when compared to free-flow traffic. Solving congestion is a key to improve economic efficiency and environmental effectiveness of transport. Doing so by improving public transport and incrementing its use seems particularly important, as the Mohring effect describes [21].

Yet, people's behaviour, namely their mobility patterns, is the bedrock of any strategy aiming at sustainable mobility. Results from the future survey to the case studies' residents will provide greater insight into the specifics of such patterns and, consequently, allow a far greater detail and rigour on scenario building and policy making.

Other shortcomings in this research include the need to calculate costs for the remaining transport modes operating in the study areas. Furthermore, data on external costs must be further disaggregated in order to calculate integrated costs for each transport mode without incurring in double counting, and decisions must be made on what sources to privilege.

\section{Acknowledgements}

The authors are grateful to the Portuguese 'Ministério da Ciência, da Tecnologia e do Ensino Superior' for the Project "Costs and Benefits of Urban Dispersion on a local scale" financial support. The authors are also grateful for the financial support under the $3^{\text {rd }}$ EU Framework Program and the Portuguese 'Ministério da Ciência, da Tecnologia e do Ensino Superior' for the Ph.D. grant of H. Martins (SFRH/BD/13581/2003).

\section{References}

[1] EEA-European Environment Agency, Urban sprawl in Europe - the ignored challenge. EEA Report No.10/2006. EEA: Copenhagen, 56 p., 2006.

[2] Catalán, B., Saurí, D., Serra, P., Urban sprawl in the Mediterranean? Patterns of growth and change in the Barcelona Metropolitan Region 19932000. Landscape and Urban Planning, 85, pp.174-184, 2008.

[3] Kasanko, M., Barredo, J.I., Lavalle, C., McCormick, N., Demicheli, L., Sagris, V. Brezger, A., Are European cities becoming dispersed? A comparative analysis of fifteen European urban areas. Landscape and Urban Planning, 77, pp.111-130, 2006.

[4] Wright, F. L., The Living City, Horizon Press: New York, 224p., 1958

[5] Burchell, R.W., Lowenstein, G., Dolphin, W.R., Galley, C.C., Downs, A., Seskin, S. Still, K. G., Moore, T., Costs of Sprawl - 2000. TCRP Report 74. Washington, DC: National Academy Press, 605 p., 2002.

[6] Ewing, R., Pendall, R., Chen, D., Measuring sprawl and its transportation impacts. Transportation Research Record, 1831, pp.175-183, 2003.

[7] Heimlich, R. and Anderson, W., Development at the urban fringe and beyond: impact on agriculture and rural land. Agriculture Economic Report 
(AER803). United States Department of Agriculture, Washington, DC, 88 p., 2001.

[8] Frumkin, H., Frank, L., Jackson, R., Urban Sprawl and Public Health: Designing, Planning, and Building for Healthy Communities. Island Press, Washington, DC, 338 p., 2004.

[9] Breheny, M., Centrists, decentrists and compromisers. The compact city a sustainable urban form? eds. M. Jenks, E. Burton, Williams, K, Taylor and Francis: Oxford, 1996.

[10] Holland, M., Pye, S., Watkiss, P., Droste-Franke, B., Bickel, P., Damages per tonne emission of PM2,5, NH3, SO2, NOx and VOCs from each EU25 Member State (excluding Cyprus) and surrounding seas. Service contract for carrying out cost-benefit analysis of air quality related issues, in particular in the Clean Air for Europe (CAFE) Program, AEA Technology Environment: UK, 26 p., 2005.

[11] European Commission, ExternE. Externalities of energy. Methodology 2005 Update. ed. Bickel, P. and Friedrich, R., European Communities: Luxemburg, 270 p., 2005.

[12] Carvalho, J. \& Gomes, P., "Costs and Benefits of Urban Dispersion on a Local Scale». Presentation of an ongoing Research Project, 5. ${ }^{\circ}$ Congreso Ciudad y Territorio Virtual "Estrategias de transformación y gestión de la ciudad; perspectivas y nuevas tecnologías", Universidad Politècnica de Catalunya: Barcelona: 2009.

[13] Baum, H., Geißler, T., Schneider, J. \& Bühne, J.-A., External Costs in the Transport Sector - A Critical Review of the EC-Internalisation-Policy, Institute for Transport Economics at the University of Cologne: Cologne, 2008.

[14] Ricci, A. \& Black, I., The social costs of intermodal freight transport, Research in Transport Economics 14, pp. 245-285, 2005.

[15] EEA, Term 2001 Indicators tracking transport and environment in the European Union, Copenhagen: EEA, 2001.

[16] Pereira, T.C., Seabra, T., Maciel, H. \& Torres, P., Portuguese National Inventory Report on Greenhouse Gases, 1990-2007. Submitted under the United Nations Framework Convention on Climate Change and Kyoto Protocol, Portuguese Environmental Agency: Amadora, 2009.

[17] ACAP, Estatísticas do Sector Automóvel 2005, ACAP: Lisboa, 2006.

[18] European Parliament, Resolução legislativa do Parlamento Europeu, de 22 de Outubro de 2008, sobre uma proposta alterada de directiva do Parlamento Europeu e do Conselho relativa à promoção de veículos de transporte rodoviário não poluentes e energeticamente eficientes (COM(2007)0817 - C6-0008/2008 - 2005/0283(COD)), European Parliament: Strasbourg, 2008.

[19] INFRAS/IWW, External Costs of Transport. Accident, Environment and Congestion Costs in Western Europe, International Union of Railways: Paris, 2000. 
[20] Santos, B., Santos, L. P., Cavaleiro, V., Custos dos Utentes na Gestão da Rede Rodoviária Nacional, Congresso Rodoviário Português, Centro Rodoviário Português: Estoril, 2008.

[21] Quinet, Emile, A meta-analysis of Western European external costs estimates. Transportation Research D 9, pp. 465-476, 2004.

[22] Macário, R., Carmona, M. Caiado, G. et al., UNITE (UNification of accounts and marginal costs for Transport Efficienty) Deliverable 12, Annex 7, The Pilot Accounts for Portugal. Funded by $5^{\text {th }}$ Framework RTD Programme. ITS, University of Leeds: Leeds, 2003.

[23] INFRAS/IWW, External Costs of Transport, Update Study. Final Report. Paris: International Union of Railways, 2004. 